\title{
ON THE OCCASION OF THE 8OTH ANNIVERSARY OF THE ACADEMICIAN OF THE RUSSIAN ACADEMY OF SCIENCES, RECTOR OF MOSCOW STATE UNIVERSITY M.V. LOMONOSOV V. A SADOVNICHY
}

DOI: $10.20948 /$ mathmontis-2019-46-12

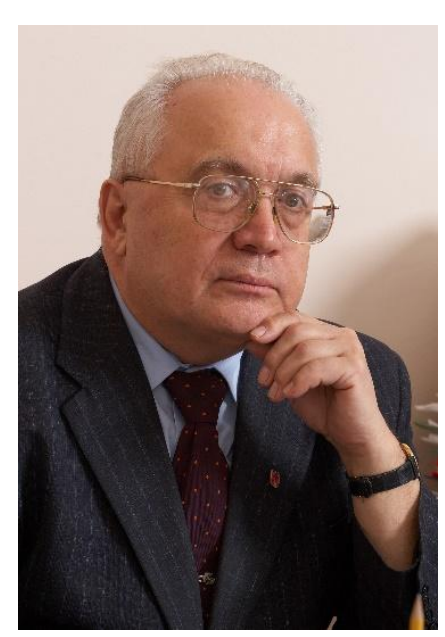

Viktor Antonovich Sadovnichy, member of the Mathematica Montisnigri Editorial Board, celebrates its 80th anniversary this year.

Academician of the Russian Academy of Sciences, Professor V.A. Sadovnichiy is an outstanding Soviet and Russian mathematician, a major organizer of science and education, a wellknown specialist in the field of computer science and applied mathematics, rector of Moscow State University, a member of many foreign Academies and Universities, including an honorary doctor of the University of Montenegro, a foreign member of the Montenegrin Academy of Sciences and arts. He authored fundamental works in mathematics and mechanics, and has a number of important applied results. The mathematical works relate to the field of theory of differential operators, the mathematical justification of a number of approaches in the relativistic theory of gravity. In works devoted to the spectral theory of non-self-adjoint operators, he proposed and developed analytical methods and ideas for studying operators with a complex occurrence of a parameter. V.A. Sadovnichy investigated the most important problem of mathematical physics - the Orr-Sommerfeld problem, which arises in the theory of hydrodynamic stability, and the boundary-value problem for the Bessel equation, and here an operator with an unbounded potential was considered for the first time in the theory of traces of the discrete operators.

The mathematicians at the University of Montenegro are grateful to Academician V.A. Sadovnichy for his mentoring, help and support provided in developing the scientific potential of the Montenegrin School of Mathematics, especially in difficult times of the blockade and isolation of Yugoslavia by Western countries.

The editorial board of the journal Mathematica Montisnigri wishes Viktor Antonovich good health, long and fruitful activities as the rector of M.V. Lomonosov Moscow State University and further successes in the development of theoretical and applied mathematics.

Mathematica Montisnigri Editorial Board 


\section{К 80-ЛЕТИЮ СО ДНЯ РОЖДЕНИЯ АКАДЕМИКА РОССИЙСКОЙ АКАДЕМИИ НАУК, РЕКТОРА МОКОВСКОГО ГОСУДАРСТВЕННОГО УНИВЕРСИТЕТА ИМ. М.В. ЛОМОНОСОВА В. А САДОВНИЧЕГО}

DOI: $10.20948 /$ mathmontis-2019-46-12

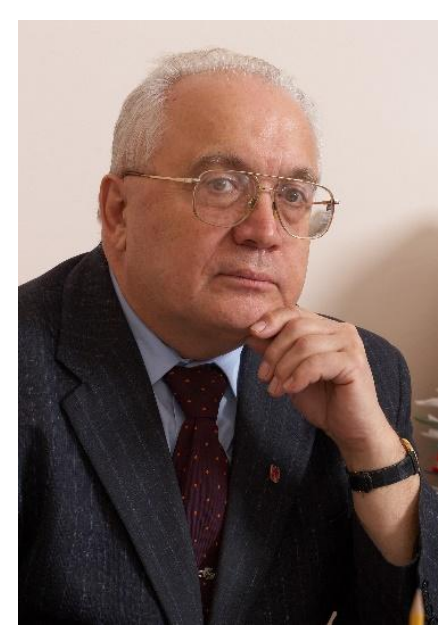

Член Редакционной коллегии журнала Mathematica Montisnigri Виктор Антонович Садовничий в этом году отмечает 80-летний юбилей.

Академик Российской академии наук, профессор В.А. Садовничий - выдающийся советский и российский ученыйматематик, крупный организатор науки и образования, известный специалист в области информатики и прикладной математики, ректор МГУ, член многих иностранных Академий и Университетов, в том числе является почетным доктором Университета Черногории, иностранным членом Черногорской Академии наук и искусств. Ему принадлежат фундаментальные труды в математике, механике, ряд важных результатов прикладного характера. Математические труды относятся к области теории дифференциальных операторов, математическому обоснованию ряда подходов в релятивистской теории гравитации. В работах, посвященных спектральной теории несамосопряженных операторов, им предложены и развиты аналитические методы и идеи изучения операторов со сложным вхождением параметра. В.А. Садовничий исследовал важнейшую задачу математической физики - задачу Орра-Зоммерфельда, возникающую в теории гидродинамической устойчивости, и краевую задачу для уравнения Бесселя, причем здесь впервые в теории следов дискретных операторов был рассмотрен оператор с неограниченным потенциалом.

Математики Университета Черногории благодарны академику В.А. Садовничему за наставничество, помощь и поддержку, оказанную в развитии научного потенциала Черногорской математической школы, особенно в трудные времена блокады и изоляции Югославии западными странами.

Редколлегия журнала Mathematica Montisnigri желает Виктору Антоновичу крепкого здоровья, долгой и плодотворной деятельности на посту ректора МГУ им. М.В. Ломоносова и дальнейших успехов в дальнейшем развитии теоретической и прикладной математики.

Редколлегия журнала Mathematica Montisnigri 